\title{
Profil Career Adaptability Mahasiswa Bidikmisi Universitas Negeri Semarang (UNNES)
}

\section{Sinta Saraswati, Binti Isrofin, Edwindha Prafitra N}

\author{
KORESPONDEN PENULIS: \\ Sinta Saraswati \\ Universitas Negeri Semarang \\ Jalan Sekaran Gunungpati, Semarang, \\ Indonesia \\ Email: sinta.fip@gmail.com \\ Binti Isrofin \\ Universitas Negeri Senarang \\ Jalan Sekaran Gunungpati, Semarang, \\ Indonesia \\ Email:bintiisrofin@mail.unnes.ac.id
}

Edwindha Prafitra N

Universitas Negeri Semarang

Jalan Sekaran Gunungpati, Semarang, Indonesia

Email: edwindhapn@gmailcom

Halaman

98-103

\begin{abstract}
This study aimed to find out the profile of Bidikmisi students at Semarang State University (UNNES). This was a quantitative study with descriptive survey design. The subject of this study was 462 university students who were taken by simple random sampling technique. The data were collected by using career adaptability scale. The data were analyzed by using descriptive statistics. Based on the result of the analysis, it was found that the average profile of UNNESS Bidikmisi students' career adaptability was $51 \%$ and was categorized as high. The result of this study shows that the attempts in improving students' career adaptability by the lecturers, parents, and university counselors are needed.

Keywords: career adaptability, bidikmisi scholarship, descriptive survey
\end{abstract}

\section{ABSTRAK}

Tujuan studi ini untuk mengetahui profil career adaptability mahasiswa bidik misi Universitas Negeri Semarang (UNNES). Studi menggunakan pendekatan kuantitatif dengan jenis survey diskriptif. Jumlah subjek dalam studi ini sebanyak 462 mahasiswa yang ditentukan melalui teknik simple random sampling. Pengumpulan data menggunakan instrumen skala career adaptability. Teknik analisis data menggunakan statistik deskriptif. Berdasarkan hasil analisis diketahui bahwa rata-rata profil career adaptability mahasiswa bidikmisi UNNES sebesar $51 \%$ berada pada kategori tinggi. Hasil studi tersebut menunjukkan bahwa diperlukan upaya untuk meningkatkan career adaptability mahasiswa oleh dosen, orangtua, dan konselor di perguruan tinggi.

Kata kunci: adaptabilitas karier, mahasiswa bidikmisi, survei deskriptif

\section{PENDAHULUAN}

Karier merupakan kolaborasi dari semua peran kehidupan yang dimainkan oleh seseorang di titik waktu tertentu. Hal ini senada dengan pendapat Atmaja 
(2014) yang menyatakan bahwa karir merupakan suatu keseluruhan peran kehidupan seseorang dalam perwujudan diri untuk menjalani hidup dan mencapai tujuan. Peran kehidupan yang dimaksudkan termasuk ketika menjadi seorang anak, siswa/mahasiswa, pekerja, pasangan, orangtua, pengurus rumah tangga, maupun warga negara. Oleh karena itu, setiap individu hendaknya memiliki career adaptability agar mampu menyesuaikan diri dengan perubahan yang tidak terprediksi pada kondisi tertentu terkait dengan peran kehidupan. Individu yang memiliki kesiapan dan mampu menetapkan strategi akan memperbesar peluang mendapatkan pekerjaan yang sesuai sehingga dapat mencapai kesuksesan karier dan kesejahteraan hidup (Abdillah, 2014).

Mahasiswa dalam masa transisi dari pendidikan di Sekolah Menengah Atas (SMA) ke pendidikan di perguruan tinggi akan menghadapi banyak kesulitan dan permasalahan dalam belajar, kemandirian, keterampilan interpersonal, keadaaan mental, dan lain sebagainya (Feng, 2015; Duffy, Douglass, \& Autin, 2015; Koen, Klehe, \& Vianen, 2012). Ketidaksiapan menghadapi berbagai perubahan pada masa ini dapat menyebabkan problema. Banyak tantangan yang harus dihadapi mahasiswa tahun pertama dan kedua. Tantangan yang dimaksud dibagi menjadi tiga kategori yaitu tantangan akademik, tantangan perkembangan, dan tantangan institusional. Tantangan akademik misalnya mahasiswa harus menghadapi perbedaan model pembelajaran di perkuliahan. Tantangan perkembangan seperti perubahan masa remaja menuju dewasa yang berpengaruh terhadap kondisi fisik dan psikis. Tantangan institusional contohnya peraturan dari perguruan tinggi yang diberlakukan bagi mahasiswa.

Berdasarkan hasil studi yang telah dilakukan oleh Arbarini dan Yusuf (Arbarini, Fakhrudin, \& Ekosiswoyo, 2016) disebutkan bahwa daya serap alumni Program Studi Pendidikan Luar Sekolah (PLS) dalam dunia kerja masih rendah. Para alumni jurusan PLS pun juga menjadi kelompok pengangguran putus asa (discourage unemployment) yaitu pengangguran sudah bertahun-tahun mencari kerja tanpa hasil karena faktor demand for labor dan supply for labor yang semakin tidak seimbang. Ketidakseimbangan itu terjadi ketika lebih besar penawaran tenaga kerja daripada permintaan tenaga kerja hampir di seluruh sektor industri. Kondisi inilah yang menjadikan kekhawatiran dan ancaman bagi mahasiswa. Berdasarkan hasil studi tersebut, dapat diungkap pentingnya career adaptability pada mahasiswa.

Studi bertujuan untuk mengetahui profil career adaptability bagi mahasiswa bidikmisi Universitas Negeri Semarang. Mahasiswa yang memiliki career adaptibility akan menjadi pribadi yang kuat secara mental dan mudah beradaptasi dengan berbagai kondisi pasca kelulusannya nanti. Hasil studi dapat dijadikan sebagai bahan kajian untuk mengembangkan program dalam membantu mahasiswa meningkatkan career adaptability.

\section{METODE PENELITIAN}

Studi menggunakan pendekatan kuantitatif dengan jenis survey diskriptif. Jumlah subjek dalam studi sebanyak 462 mahasiswa Bidik Misi UNNES semester 1-5 dari delapan Fakultas yaitu Fakultas IImu Pendidikan (FIP), Fakultas IImu Keolahragaan (FIK), Fakultas Matematika dan Ilmu Pengetahuan Alam (FMIPA), Fakultas IImu Sosial (FIS), Fakultas Bahasa dan Sastra (FBS), Fakultas Ekonomi (FE), dan Fakultas Teknik (FT). Subjek dalam studi ini ditentukan melalui tekniksimple random sampling. Pengumpulan data menggunakan instrumen skala career adaptability. Teknik analisis data yang digunakan analisis statistik deskriptif.

\section{HASIL DAN PEMBAHASAN}

Hasil studi menunjukkan bahwa profil career adaptability mahasiswa bidikmisi UNNES sebagian besar berada pada kategori tinggi dengan prosentase $51 \%$. Prosentase tersebut dapat berarti bahwa sebagian besar mahasiswa bidikmisi UNNES memiliki kesiapan yang bagus dalam menghadapi tugas dan peran yang terprediksi maupun tidak terprediksi. Artinya, dengan adanya peran adaptabilitas karier memberikan beberapa manfaat seperti meningkatkan pemahaman terhadap kemampuan, komitmen dan minat, meningkatkan kualitas kerja untuk mencapai kepuasan hidup, serta mempersiapkan diri menghadapi hambatan melalui perencanaan karier. Rottinghaus, Day, \& Borgen (Creed, Fallon, \& Hood 2009) mendefinisikan adaptabilitas karier sebagai kecenderungan yang mempengaruhi cara seseorang dalam melihat kapasitasnya untuk merencanakan dan menyesuaikan diri dengan rencana perubahan-perubahan dalam kariernya, terutama dalam menghadapi hal- 
hal yang tidak terprediksi. Secara lebih rinci, profil career adaptability mahasiswa bidikmisi UNNES disajikan pada Tabel 1.

Tabel 1

Gambaran Umum Profil Career Adaptability Mahasiswa Bidikmisi UNNES

\begin{tabular}{lcc}
\hline \multicolumn{1}{c}{ Kategori } & \multicolumn{2}{c}{ Mahasiswa } \\
& $f$ & $\%$ \\
\hline Sangat Tinggi (ST) & 81 & $18 \%$ \\
Tinggi (T) & 235 & $51 \%$ \\
Sedang (S) & 142 & $30 \%$ \\
Rendah (R) & 4 & $1 \%$ \\
Sangat Rendah (SR) & 0 & $0 \%$ \\
\hline
\end{tabular}

Hasil analisis profil career adaptability ditinjau dari jenis kelamin menunjukkan bahwa pada subjek perempuan kategori sangat tinggi sebesar 17\%, kategori tinggi sebesar $50 \%$, kategori sedang sebesar $32 \%$, dan kategori rendah sebesar $1 \%$. Sementara itu, untuk subjek laki-laki kategori sangat tinggi sebesar 24\%, kategori tinggi sebesar 59\%, kategori sedang sebesar $16 \%$, dan kategori rendah sebesar $2 \%$. Hal ini berarti career adaptability mahasiswa bidikmisi perempuan dan laki-laki termasuk pada kategori tinggi. Namun, jika dibandingkan mahasiswa laki-laki memiliki adaptabilitas karier yang lebih tinggi dibandingkan mahasiswa perempuan. Hal ini berbeda dengan hasil studi McNair \& Brown (Mardiyati \& Yuniawati, 2015) yang menyatakan bahwa adaptabilitas karier remaja perempuan lebih tinggi daripada remaja laki-laki. Hal ini disebabkan remaja perempuan dan laki-laki memiliki pola yang berbeda terkait komponen pembentukan identitas. Perempuan membentuk identitas mereka dengan cara menjalin hubungan dengan orang lain, dan laki-laki dengan menetapkan kemandiriannya (Seligman 1994). Remaja perempuan akan mudah menggali karier yang diminati karena mereka cenderung berinteraksi dengan banyak orang.

Gambaran profil career adaptability dari 8 Fakultas yang ada di UNNES. Hasil analisis menunjukkan bahwa mahasiswa bidikmisi di Fakultas IImu Pendidikan (FIP) sebesar 15\% termasuk dalam kategori sangat tinggi, 60\% termasuk dalam kategori tinggi, 23\% termasuk dalam kategori sedang, dan sebesar $2 \%$ termasuk dalam kategori rendah. Mahasiswa bidikmisi di Fakultas Ekonomi (FE) sebesar 16\% responden termasuk dalam kategori sangat tinggi, 57\% responden termasuk dalam kategori tinggi, dan sebesar $27 \%$ responden termasuk dalam kategori sedang. Mahasiswa Fakultas Bahasa dan Sastra (FBS) diketahui sebesar 21\% termasuk dalam kategori sangat tinggi, 55\% termasuk dalam kategori tinggi, 23\% responden terletak pada kategori sedang, dan hanya $1 \%$ pada kategori rendah.

Sementara itu, hasil analisis pada mahasiswa bidikmisi di Fakultas Matematika dan IImu Pengetahuan Alam (FMIPA) diketahui sebesar 11\% termasuk dalam kategori sangat tinggi, 46\% kategori tinggi, 42\% kategori sedang, dan hanya $1 \%$ yang berada pada kategori rendah. Pada Fakultas IImu Sosial (FIS) diketahui sebesar 18\% termasuk dalam kategori sangat tinggi, 36\% dalam kategori tinggi, dan sebesar $46 \%$ pada kategori sedang. Mahasiswa pada Fakultas Hukum (FH) sebesar 25\% termasuk dalam kategori tinggi, 44\% pada kategori sedang, dan 31\% berada pada kategori rendah.

Hasil analisis career adaptability pada mahasiswa bidikmisi di Fakultas Teknik (FT) diketahui sebesar 23\% termasuk dalam kategori sangat tinggi, 45\% termasuk dalam kategori tinggi, 30\% pada kategori sedang, dan hanya 2\% berada pada kategori rendah. Mahasiswa bidikmisi di Fakultas IImu Keolahragaan (FIK) diketahui sebesar 25\% termasuk dalam kategori sangat tinggi, 58\% termasuk dalam kategori tinggi, dan sebesar $17 \%$ responden terletak pada kategori sedang. Berdasarkan hasil analisis career adaptability setiap fakultas yang telah dipaparkan, maka dapat disimpulkan bahwa profil career adaptability pada setiap fakultas dari yang tertinggi sampai dengan yang terendah seperti yang disajikan pada Tabel 2.

Tabel 2

Profil Career Adaptability pada Setiap Fakultas

\begin{tabular}{cc}
\hline Fakultas & Persentase \\
\hline FIK & $83 \%$ \\
FBS & $76 \%$ \\
FIP & $75 \%$ \\
FE & $73 \%$ \\
FT & $68 \%$ \\
FMIPA & $57 \%$ \\
FIS & $54 \%$ \\
FH & $25 \%$ \\
\hline
\end{tabular}

Tabel 2 menunjukkan profil career adaptability mahasiswa bidikmisi pada setiap fakultas. Persentase career adapt- 
ability pada Tabel 2 diperoleh berdasarkan akumulasi persentase kategori "sangat tinggi" dan kategori "tinggi" pada setiap fakultas. Berdasarkan Tabel 2, maka dapat diperoleh kesimpulan bahwa hasil career adaptability tertinggi pada Fakultas IImu Keolahragaan (FIK) dan yang terendah pada Fakultas Hukum (FH).

Adaptabilitas karier berperan penting dalam perencanaan karier remaja. Jika adaptabilitas karier remaja rendah maka remaja tidak akan memiliki perencanaan karier yang jelas. Remaja seperti itu cenderung memiliki gangguan emosi dan kepribadian seperti pesimistis, gangguan kecemasan (anxiety), konsep diri negatif, dan self esteem yang rendah (Saka, Gati, \& Kelly, 2008).

Adaptabilitas karier merupakan konstruk psikososial yang menunjukkan kesiapan individu dan sumber daya yang digunakan dalam menyesuaikan diri dengan tugas perkembangan kerja, penyesuaian dalam menghadapi transisi kerja, dan trauma personal. Hal tersebut sesuai dengan hasil studi Creed \& Patton (2003) yang menunjukkan bahwa kemampuan remaja menyesuaikan diri dengan tugas perkembangan dalam hal karier, dapat dikatakan remaja tersebut telah memenuhi harapan sosial dan masyarakat. Berdasarkan pernyataan tersebut, adaptabilitas karier dimaknai sebagai kesiapan mengatasi tugas dan turut berperan dalam pekerjaan, serta mampu mengatasi perubahan kondisi kerja sebagai wujud memenuhi harapan sosial masyarakat. Selanjutnya, Rottinghaus, Day, \& Borgen (Creed, Fallon, \& Hood, 2009) mendefinisikan adaptabilitas karier sebagai kecenderungan yang mempengaruhi cara seseorang dalam melihat kapasitasnya untuk merencanakan dan menyesuaikan diri dengan rencana perubahan-perubahan dalam kariernya, terutama dalam menghadapi hal-hal yang tidak terprediksi. Berdasarkan beberapa definisi adaptabilitas karier yang telah dipaparkan, maka dapat dimaknai bahwa mahasiswa yang di masa mendatang dituntut terlibat dalam dunia pekerjaan, sudah sepantasnya mengembangkan adaptabilitas karier sedini mungkin agar dapat menjadi lulusan yang siap mental dan profesional (Hartung, Porfeli, \& Vondracek, 2008; Savickas \& Porfeli. 2012)..

Adaptabilitas karier merupakan konseptualisasi tertinggi dari suatu karier, dimana terdiri dari beberapa dimensi antara lain perhatian (concern), pengendalian (control), keingintahuan (curiosity), dan kepercayaan diri (confidence). Re- maja yang memiliki tingkat adaptabilitas karier lebih tinggi, dilihat dari segi pengambilan keputusan karier, perencanaan karier, eksplorasi karier, dan perasaan percaya diri akan memiliki tingkat kesuksesan yang lebih baik dalam menguasai transisi vokasional (Creed et al., 2003).

Hasil studi yang dilakukan oleh (Hirschi, 2009) menunjukkan bahwa adaptabilitas karier memiliki hubungan yang positif terhadap perkembangan remaja. Studi tersebut dilakukan untuk menguji efek dari adaptabilitas karier terhadap perkembangan positif remaja seperti kepuasan hidup, perasaan memiliki kekuatan, dan well-being. Hasil studi menunjukkan bahwa adaptabilitas karier merupakan prediktor positif dari perkembangan positif remaja yang berupa perasaan memiliki kekuatan. Hasil studi juga menunjukkan bahwa adaptabilitas karier memiliki hubungan positif terhadap kepuaasan hidup. (Hirschi, 2009; Duffy \& Blustein, 2005)

Lebih lanjut Hirschi (2009) memaparkan faktor yang mempengaruhi adaptabilitas karier antara lain usia, gender, pengalaman kerja, keluarga, institusi pendidikan, dan status sosial ekonomi. Usia seseorang dapat menentukkan pola pikirnya. Misalnya individu pada usia remaja memiliki adaptabilitas karier lebih tinggi daripada individu usia anakanak. Remaja sudah mengerti tentang implikasi jangka panjang dari pendidikan dan pilihan karier yang sudah dilakukannya (Steinberg, 1999).

Remaja perempuan dan laki-laki memiliki pola yang berbeda terkait komponen pembentukan identitas. Seligman (1994) menyatakan bahwa perempuan membentuk identitas dengan cara menjalin hubungan dengan orang lain, sedangkan laki-laki dengan menetapkan kemandiriannya. Oleh karena itu sangat diwajarkan jika adaptabilitas karier pada perempuan lebih tinggi daripada laki-laki karena perempuan lebih banyak berinteraksi dengan banyak orang sehingga perempuan cenderung lebih mudah menggari informasi karier sesuai dengan yang diminati.

Berkaitan dengan faktor pengalaman kerja, ketika individu memiliki pengalaman kerja yang sesuai dengan minat dan kemampuannya, individu tersebut mendapatkan informasi terkait dengan karier yang dipilihnya. Penelitian yang dilakukan Luzzo, mengenai individu yang memiliki pengalaman kerja yang terkait dengan minat kariernya maka ia akan merasa bahwa pengambilan keputusan dalam 
kariernya sebagai proses berkelanjutan dimana mereka memiliki kontrol personal akan hal itu (Patton \& Lokan 2006). Berdasarkan pernyataan tersebut dapat disimpulkan bahwa semakin banyak pengalaman pekerjaan seseorang yang sesuai dengan minat dan kemampuannya, maka akan semakin tinggi tingkat adaptabilias kariernya.

Hubungan antara orangtua dan anak merupakan salah satu hal penting dalam keluarga. Melalui pola hubungan keluarga dapat diketahui arah pendidikan dan ekspektasi terhadap anak dari orangtua. Remaja yang memiliki hubungan erat dengan keluarga, justru dapat mengalami kesulitan dalam menguasai tugas-tugas perkembangan karier karena anak sering kali tidak mampu membedakan antara tujuan hidupnya dan harapan orangtuanya. Hal tersebut senada dengan hasil studi Esters dan Bowen (Juwitaningrum, 2013) menemukan bahwa orangtua (ibu dan ayah) merupakan faktor pertama yang berpengaruh terhadap pilihan karier anak mereka.

Tuntutan terhadap mutu dan kualitas pendidikan di Indonesia menyebabkan sejumlah sekolah mulai mengadakan pendidikan di luar pelajaran utama yang berkaitan dengan penjurusan di dunia perkuliahan dan alternatif karier terkait jurusan tersebut. Patton \& Lokan (2006) meyakini bahwa perbedaan institusi pendidikan yang diikuti individu memiliki peranan yang penting dalam adaptabilitas karier. Hal itu disebabkan pengalaman yang diperoleh individu pada masing-masing institusi pendidikan berbeda-beda, tergantung dengan program pengembangan diri pada masing-masing institusi pendidikan. Selain itu, status sosial ekonomi juga dapat berpengaruh pada adaptabilitas karier. Terkait dengan hal tersebut, individu dengan status sosial ekonomi yang lebih tinggi akan memiliki kesempatan yang lebih besar dalam rangka eksplorasi karier dan perencanaan kariernya.

\section{SIMPULAN}

Hasil studi menunjukkan bahwa sebesar 18\% mahasiswa bidikmisi UNNES berada dalam kategori career adaptability sangat tinggi, 51\% berada dalam kategori tinggi, $30 \%$ berada dalam kategori sedang, dan hanya 1\% berada dalam kategori rendah. Hasil studi tersebut membuktikan bahwa masih diperlukan program/strategi dari institusi perguruan tinggi untuk membantu mahasiswa mengembang- kan adaptabilias kariernya melalui unit pelaksana layanan bimbingan dan konseling di perguruan tinggi.

\section{REFERENSI}

Atmaja, Twi Tandar. (2014). Upaya Meningkatkan Perencanaan Karir Siswa melalui Bimbingan Karir dengan Penggunaan Media Modul, PSIKOPEDAGOGIA Jurnal Bimbingan dan Konseling, 3 (2), 58. 67.

Abdillah, Husni. (2014). Bimbingan Karier Berdasarkan Pendekatan Naratif untuk Meningkatkan Adaptabilitas Karier Peserta Didik. Jurnal Buana Pendidikan, 18, 13-22.

Arbarini, M., Fakhrudin, \& Ekosiswoyo, R. (2016). Tracer Study Alumni Pendidikan Luar Sekolah FIP UNNES. Jurnal Edukasi, 1 (2).

Creed, P.A., Fallon, T., dan Hood, M. (2009). "The Relationship Between Career adaptability, Person and Situation Variables, and Career Concerns In Young Adults". Journal of Vocational Behavior, 74, 219-229.

Creed, P. A. \& Patton, W.A. (2003). Predicting Two Components of Career Maturity in School Based Adolescents. Journal of Career Development, 29 (4), 277-290.

Duffy, R.D. \& Blustein, D.L. (2005). The Relationship Between Spirituality, Religiousness and Career Adaptability. Journal of Vocational Behavior, 67, 429-440.

Duffy, Ryan D., Douglass, R.P., \& Autin, K.L. (2015). Career Adaptability and Academic Satisfaction: Examining Work Volition and Self Efûcacy as Mediators. Journal of Vocational Behavior, 90, 46-54.

Feng, Zhao. (2015). Analysis and Countermeasures of University Freshmen's Adaptability in China. Journal English Language Teaching, 3 (2): 5-8.

Hartung, P.J., Porfeli, E.J., \& Vondracek, F.W. (2008). Career adaptability in Childhood. The Career Development Quarterly Journal, 57, 63-74.

Hirschi, A. (2009). Career adaptability Development in Adolescence: Multiple Predictors and Effect on Sense of Power and Life Satisfaction. Journal of $V_{0}$ cational Behavior, 74 (2), 145-155.

Juwitaningrum, Ita. (2013). Program Bimbingan Karir untuk Meningkatkan Kematangan Karir Siswa SMK. PSIKOPEDAGOGIA Jurnal Bimbingan dan 
Konseling, 2 (2), 132-147.

Koen, J., Klehe, U. C., \& Vianen, A. E. M. (2012). Training Career Adaptability to Facilitate a Successful School-to-Work Transition. Journal of Vocational Behavior, 81, 395-408.

Mardiyati, B. D. \& Yuniawati, R. (2015). Perbedaan Adaptabilitas Karir Ditinjau dari Jenis Sekolah, Jurnal Empathy, 3 (1), 31-41.

Patton, W. \& Lokan, J. (2006). Perspectives on Donald Super's Construct of Career Maturity. International Journal for Educational and Vocational Guidance, 1, 31-48.

Saka, N., Gatti, I., Kelly KR. (2008). Emotional and Personality Related Aspects of Career Decision Making Difficulties. Journal of Career Assessment, 16 (4), 403- 424.

Savickas,M.L. \& Porfeli. (2012). Career Adapt-Abilities Scale: Construction, Reliability, and Measurement Equivalence Across 13 Countries. Journal of Career Assessment, 80 (3), 661-673.

Seligman, L. (1994). Developmental Career Counseling and Assessment 2nd Edition. California: Sage.

Steinberg, L. D. (1999). Adolescence 5th Edition. USA: McGraw-Hill, Inc. 